\title{
Mladi s problemima kockanja - koliko kockaju i kako vide industriju igara na sreću
}

\author{
Neven Ricijaš \\ Edukacijsko-rehabilitacijski fakultet Sveučilišta u Zagrebu, Zagreb, Hrvatska
}

Sažetak: lako formalnim zakonom zabranjeno, kockanje maloljetnika i razvoj štetnih psihosocijalnih posljedica povezanih s kockanjem koje vode simptomima ovisnosti o kockanju, i u Hrvatskoj i u većini drugih zemalja zapadnog društva, zaokupljaju pozornost mnogih stručnjaka i znanstvenika u području mentalnog zdravlja. Svrha ovog rada je istražiti razlike u učestalosti kockanja mladih s obzirom na razinu razvijenih štetnih psihosocijalnih posljedica, te specifično njihovu percepciju dostupnosti i pristupačnosti igrama na sreću u Hrvatskoj.

$\mathrm{U}$ istraživanju je sudjelovao prigodni uzorak od N = 615 muških srednjoškolaca iz Zagreba i Splita (Mdob = 16,16 ; SDdob $=1,21$ ) svih triju vrsta obrazovnih programa, od prvog do završnog razreda srednje škole. Uz osnovne sociodemografske varijable, u istraživanju je korišten Upitnik aktivnosti kockanja, Subskala opće mjere ozbiljnosti problema povezanih s kockanjem (GPSS) te Upitnik percepcije industrije igara na sreću. Za ostvarivanje ciljeva, uz deskriptivnu i korelacijsku statistiku, korištene su parametrijske i neparametrijske metode inferencijalne statistike (ANOVA/Kruskal-Wallisov test s pripadajućim post-hoc testovima).

Rezultati pokazuju da mladi koji prema GPSS-u imaju visoku razinu štetnih psihosocijalnih posljedica povezanih s kockanjem (tzv. crveno svjetlo) sve igre igraju učestalije, a posebno visokorizične kao što su sportsko klađenje i igre na automatima. Također, percipiraju igre dostupnijima maloljetnicima unatoč zakonskim zabranama i misle da bi država trebala propisati nižu dob (maloljetništvo) za legalno uključivanje u igre na sreću u Hrvatskoj. Rezultati jednoznačno upućuju na intenzivnije rizično ponašanje mladih koji su razvili psihosocijalne probleme povezane s kockanjem, te njihovu liberalniju percepciju industrije igara na sreću i percepciju o većoj pristupačnosti pojedinim igrama.

Zaključno se rezultati stavljaju u kontekst dosadašnjih istraživanja o učestalosti kockanja mladih u Hrvatskoj i posrednom značaju utjecaja tržišta igara na sreću na stavove mladih i normalizaciju ove rizične industrije s obzirom na tako izraženu dostupnost i pristupačnost u našoj zemlji.

Ključne riječi: kockanje, igre na sreću, adolescenti, industrija igara na sreću, ovisnost o kockanju 


\section{UVOD}

Kockanje mladih kao rizično ponašanje globalno je sve češće predmet istraživanja u znanstvenoj zajednici, a razlog tome je značajna ekspanzija tržišta u svim razvijenim zemljama te svojevrsna liberalizacija dostupnosti unatoč zakonskoj zabrani pristupačnosti igara na sreću maloljetnicima (Abbott, Volberg, Bellringer i Reith, 2004; Vasiliadis, Jackson, Christensen i Francis, 2013). Industrija kockanja/igara na sreću jedna je od najbrže rastućih industrija na svijetu (Sulkenen i sur., 2019) te se značajan porast dostupnosti manifestirao i u hrvatskom okruženju posljednjih dvadesetak godina (Ricijaš, Dodig Hundrić, Huić i Kranželić, 2016). I dok danas u Hrvatskoj imamo oko petnaest puta više prodajnih mjesta priređivača igara na sreću u odnosu na stanje krajem 20. stoljeća, izmjenama Zakona o igrama na sreću iz 2009. godine (NN 87/09, 35/13, $158 / 13,41 / 14,143 / 14)$ sve igre na sreću zakonom su zabranjene maloljetnim osobama od 1.1.2010. godine. Do tada su lutrijske igre bile dopuštene mladima od 16 godina nadalje. $\mathrm{S}$ teorijskog aspekta, dostupnost i pristupačnost dio su šireg pojma koji nazivamo 'izloženost kockanju', odnosno kockarskim mogućnostima (engl. gambling exposure). Ona se definira kao mjera u kojoj populacija, ili dio neke populacije, dolazi u kontakt s kockanjem (Abbott, 2007.). Dostupnost (engl. availability) se odnosi na postojanje određenog sadržaja na nekom prostoru, dok je pristupačnost (eng. accessibility) vezana uz mogućnost konzumacije proizvoda, odnosno doslovan pristup proizvodu. Ako je nešto dostupno, ne treba biti i pristupačno. Tako su u današnjem društvu igre na sreću djeci i maloljetnicima dostupne budući da ih okružuju, ali im ne bi trebale biti pristupačne, s obzirom na to da su im zakonom zabranjene.
Iako su na globalnoj razini igre na sreću, odnosno sve aktivnosti kockanja uglavnom zabranjene maloljetnicima (Europska Komisija, 2012; Carran, 2018; Sulkenen i sur., 2019), znanstvena istraživanja kontinuirano potvrđuju njihovu konzumaciju, slično kao i s konzumaciju alkoholnih pića i duhanskih proizvoda. Stoga ne iznenađuje činjenica da je ESPAD istraživanje 2015. godine (engl. European School Survey Project on Alcohol and Other Drugs) u svoje istraživanje uključilo varijable vezane uz učestalost kockanja tijekom posljednjih godinu dana (tzv. prošlogodišnja prevalencija). Navedeno istraživanje provedeno na ukupnom uzorku od n $=93875$ šesnaestogodišnjaka iz 33 europske zemlje pokazuje da je $22.6 \%$ njih imalo iskustvo kockanja tijekom prošle godine, točnije $18,5 \%$ njih na prodajnim mjestima (engl. off-line), a 16,2\% kockanjem putem interneta (engl. on-line) (Molinaro i sur. 2018). Specifično za Hrvatsku, rezultati pokazuju prošlogodišnje iskustvo kockanja kod 26,5\% šesnaestogodišnja$\mathrm{ka}, \mathrm{s}$ podjednakim udjelom putem interneta $(21,9 \%)$ i na zemaljskim prodajnim mjestima (22,5\%). Takvi podaci stavljaju Hrvatsku na 8. mjesto po učestalosti kockanja mladih u odnosu na sve 33 zemlje, pri čemu je visoka prevalencija prisutna u različitim zemljama jugoistočne Europe (Grčka, Crna Gora, Bugarska, Cipar, Sjeverna Republika Makedonija), te u Finskoj i Italiji, dok su zemlje s najnižom prevalencijom kockanja mladih Moldavija, Malta, Austrija, Nizozemska, Ukrajina, Švedska i Norveška. Slični rezultati dobiveni su u studiji Europske mreže za ovisničko ponašanje (engl. European Network for Addictive Behavior) provedenoj s n $=13284$ srednjoškolaca u sedam europskih zemalja. Njihovi rezultati pokazuju da je oko $12 \%$ mladih imalo iskustvo kockanja u posljednjih 12 mjeseci, a značajno više u Grčkoj i Rumunjskoj u odnosu na, primjerice, Španjolsku i Nizozemsku (Andrie i sur., 2019). Iz navedenog je moguće izvesti 
Ricijaš, N., Mladi s problemima kockanja - koliko kockaju i kako vide industriju igara na sreću, Klinička psihologija 13 (2020), 1-2, 47-62

zaključke kako društveni kontekst, širi društveni odnos prema rizičnim ponašanjima i konzumaciji sredstva ovisnosti, odnosno regulativa dostupnosti i pristupačnosti kockarskih aktivnosti općenito, ali i specifičnih vrsta igara s obzirom na njihovu rizičnost, doprinosi kros-nacionalnim razlikama u prevalencijskim studijama. Pritom su upravo dvije navedene studije najbolji primjeri za takve zaključke budući da je u svim zemljama korišten identični instrumentarij, te su metodološke razlike minimalne.

Istraživanja kockanja mladih u Hrvatskoj posljednjih desetak godina također bilježe porast i danas postoji dovoljan broj znanstvene literature na različitim uzorcima i u različitim sredinama iz koje proizlazi jasan zaključak o nepovoljnom utjecaju dostupnosti i pristupačnosti igara na sreću na kockanje maloljetnika. Dapače, istraživanja potvrđuju da je upravo kockanje atraktivnije mlađoj populaciji u odnosu na stariju životnu dob. Tako rezultati istraživanja provedenih na Institutu društvenih znanosti Ivo Pilar 2011. i 2015. godine, na reprezentativnom uzorku građana Republike Hrvatske, pokazuju nešto veću prevalenciju kockanja kod mlađe odrasle dobi u odnosu na starije građane (Glavak Tkalić i Miletić, 2012; Glavak Tkalić, Miletić i Sučić, 2018). Najobuhvatnije hrvatsko istraživanje kockanja mladih provedeno je na Edukacijsko-rehabilitacijskom fakultetu Sveučilišta u Zagrebu od 2011. do 2013. godine na reprezentativnom uzorku n $=2702$ hrvatska srednjoškolca u 7 hrvatskih gradova (Ricijaš i sur., 2016), te ono pokazuje kako je $72,9 \%$ srednjoškolaca kockalo barem jedanput u životu, pri čemu je sportsko klađenje najatraktivnija i najfrekventnija igra, posebno kod mladića. U odnosu na spolne razlike, mladići kockaju značajno češće od djevojaka, posebno rizičnije igre kao što su sportsko klađenje i igre na automatima, dok razlike u odnosu na vrstu škole pokazuju nešto učestalije kockanje srednjoškolaca u strukovnim programima u odnosu na gimnazijske. Kada je riječ o dobi, učenici prvih razreda kockaju nešto rjeđe, međutim efekti tih razlika nisu veliki. Slični rezultati u Hrvatskoj dobiveni su i drugim istraživanjima na prigodnim uzorcima. Tako istraživanje provedeno u Bjelovarsko-bilogorskoj županiji pokazuje kako je oko $45 \%$ srednjoškolaca kockalo barem jedanput u životu (Puharić, Kudumija Sljepčević, Badrov i Petričević, 2016), u Dubrovniku njih oko 78\% (Mikas, Šimić i Rajič, 2019), u Virovitici oko 40\% (Venus, Brlas, Šerepac, 2013), a u Zadarskoj županiji oko 60\% (Peroš, 2019; Ricijaš i Dodig Hundrić, 2019), u Zagrebu oko 75\% (Dodig i Ricijaš, 2011) i u Osijeku oko 70\% (Livazović i Bojčić, 2017). U svim navedenim istraživanjima konzistentan je nalaz kako je kockanje učestalije među mladićima, te je sportsko klađenje najfrekventnija igra na sreću, a istraživanja na našim prostorima pokazuju i da je učestalost kockanja također u pozitivnoj korelaciji s manifestacijom drugih oblika rizičnog ponašanja (Dodig, 2013; Ricijaš, Dodig Hundrić i Kranželić, 2015; Livazović i Bojčić, 2019), što je u skladu i s rezultatima inozemnih istraživanja (Hardoon i Derevensky, 2002; Volberg, Gupta, Griffiths, Olason i Delfabbro, 2010; Castren, Grainger, Lahti i Salonen, 2015; Molinaro i sur. 2018). Valja naglasiti da je određene prevalencijske razlike moguće pripisati i razlikama u metodologiji, odnosno načinu mjerenja kockanja i njegove učestalosti. Dok neka istraživanja postavljaju opće pitanje o generalnoj životnoj prevalenciji sudjelovanja u igrama na sreću, neka istraživanja koriste detaljnije upitnike (skale i ček-liste) iskustva kockanja s nizom ponuđenih igara, čime se dobivaju specifičniji podaci.

Kockanje je rizična aktivnost upravo zbog mogućnosti razvoja ovisnosti, odnosno niza štetnih psihosocijalnih posljedica povezanih s kockanjem. Iako instrumenti procjene problema/štetnih posljedica ne uključuju varijable 
same učestalosti kockanja, logično je da postoji pozitivna korelacija između učestalosti kockanja i razvoja problema, odnosno simptoma ovisnosti (Delfabbro, Lahn i Grabosky, 2006; Castren i sur., 2015; Dodig, 2013; de Luigi, Gibertoni, Randon i Scorcu, 2017). Stoga je prevalenciju štetnih simptoma problematičnog kockanja kod mladih na globalnoj razini također potrebno sagledavati unutar nacionalnog okvira priređivanja igara na sreću u pojedinoj jurisdikciji, odnosno dostupnosti i pristupačnosti igara unatoč zakonskim zabranama. O tome najbolje svjedoči analiza 44 međunarodne studije Calado, Alexandrea i Griffithsa (2017) kojom je utvrđeno da kriterije za problematično kockanje zadovoljava od $0,2 \%$ do visokih $12,3 \%$ mladih, s potonjom frekvencijom upravo na našim prostorima. Ovom analizom, osim različitih država/jurisdikcija, prikazani su i prevalencijski podaci na temelju različitih instrumenata procjene štetnih posljedica, odnosno problematičnog kockanja mladih.

Upotrebljavajući Kanadski upitnik kockanja adolescenata (Tremblay, Stinchfield, Wiebe i Wynne, 2010) istraživanje Ricijaša i sur. (2016) na reprezentativnom uzorku srednjoškolaca pokazuje kako 12,9\% njih zadovoljava kriterije za ozbiljnu razinu štetnih psihosocijalnih posljedica povezanih s kockanjem (tzv. crveno svjetlo), te taj udio raste na čak $23,7 \%$ kada se izdvoji subuzorak mladića. Istim instrumentom, istraživanje provedeno u Zadarskoj županiji na prigodnom uzorku srednjoškolaca pokazuje da njih 7,1\% zadovoljava kriterije za crveno svjetlo, odnosno točnije 9,4\% mladića (Peroš, 2019; Ricijaš i Dodig Hundrić, 2019), dok je taj postotak u Bosni i Hercegovini 8,3\% (Bijedić, Kuralić-Čišić, Kovačević i Vardo, 2015). Iako se rezultati o zastupljenosti problematičnog kockanja među mladima razlikuju s obzirom na korištene instrumente, valja naglasiti kako je korištenjem DSM-IV-J instrumenta procjene na prigodnom uzorku zagrebačkih srednjoškolaca utvrđen udio od 7,5\% problematičnih kockara, odnosno njih 11,4\% korištenjem SOGS-RA instrumenta procjene (Dodig i Ricijaš, 2011). Kada je riječ o općoj populaciji hrvatskih građana od 15 do 65 godina života, istraživanje Glavak Tkalić, Miletić i Sučić (2017), koristeći PGSI instrument procjene problematičnog kockanja, pokazuje da 9,4\% građana ima neku vrstu problema (barem blagu) povezanih s kockanjem, odnosno čak $12,8 \%$ kada se izdvoje oni mlađe dobi (od 15. do 34. godine). Specifično, 2,2\% svih građana i 3,2\% svih mlađih građana zadovoljava kriterije za ozbiljno problematično kockanje.

Sva dosadašnja istraživanja na našim prostorima uglavnom su mjerila učestalost kockanja mladih i razlike s obzirom na neka sociodemografska obilježja (spol, dob/razred, vrsta škole i slično) te prediktore, odnosno korelate razvoja problema. Međutim, nedostaju istraživanja nekih drugih aspekata razumijevanja kockanja mladih koji su razvili probleme u odnosu na one koji nisu. Stoga je svrha ovog rada istražiti razlike u učestalosti kockanja mladih s obzirom na razinu razvijenih štetnih psihosocijalnih posljedica te specifično njihovu percepciju dostupnosti i pristupačnosti igrama na sreću u Hrvatskoj. Prema spoznaji autora, te analizom dostupne domaće i međunarodne literature, ne postoje istraživanja koja su se bavila percepcijom industrije, odnosno tržišta igara na sreću maloljetnika, te samoiskazanom lakoćom pristupa pojedinačnim igrama na sreću. Temeljna je pretpostavka da će mladi koji su razvili ozbiljne psihosocijalne probleme povezane s kockanjem učestalije igrati visokoadiktivne/rizičnije igre, te da će industriju igara na sreću percipirati liberalnijom i kao više pristupačnom maloljetnicima u odnosu na mlade koji nemaju štetne posljedice, odnosno koji ne kockaju toliko intenzivno. 
Ricijaš, N., Mladi s problemima kockanja - koliko kockaju i kako vide industriju igara na sreću,

\section{METODOLOGIJA}

\section{Uzorak sudionika}

$\mathrm{U}$ istraživanju je sudjelovalo ukupno $\mathrm{N}$ $=615$ mladića iz Zagreba $(52,9 \%)$ i Splita $(47,1 \%)$, svih triju hrvatskih srednjoškolskih programa: gimnazijski program $(23,5 \%)$, strukovni četverogodišnji program $(42,2 \%)$ i strukovni trogodišnji program (34,4\%). Hikvadrat testom nisu utvrđene razlike u zastupljenosti različitih vrsta srednjoškolskih programa s obzirom na grad $\left(\chi^{2}=4,15 ; \mathrm{p}>, 050\right)$. Uzorak u oba grada čine učenici svih razreda, od prvog do završnog (1. razred $=29,4 \% ; 2$. razred $=28,6 \% ; 3$. razred $=25,0 \% ; 4$. razred =16,9\%), tako da je raspon dobi od 14 do 19 godina, a prosječna dob je Mdob = 16,16 godina života (SDdob $=1,21)$. Uzorak je prigodan.

\section{Mjerni instrumenti}

Ovo istraživanje sastavni je dio znanstvenog projekta "Kockanje mladih u Hrvatskoj" i potpore istraživanjima Sveučilišta u Zagrebu koji se provode na Edukacijsko-rehabilitacijskom fakultetu u Zagrebu. Uz upitnik o osnovnim osobnim i sociodemografskim obilježjima mladih (spol, dob, razred, grad/mjesto boravišta), u ovom istraživanju korišteni su sljedeći instrumenti:

\section{Upitnik aktivnosti kockanja}

U istraživanju je korištena skraćena i modificirana verzija Upitnika aktivnosti kockanja (Ricijaš i sur., 2011) sa 6 vrsta igara na sreću koje su se u dosadašnjim hrvatskim istraživanjima pokazala najviše zastupljenima među mladima (loto, jednokratne srećke/strugalice, sportsko klađenje, igre na automatima, rulet u casinu i kartanje za novac s prijateljima). Pritom je važno napomenuti da posljednja igra nije formalni oblik kockanja uređen od strane priređivača igara na sreću, već neformalno vršnjačko kockanje. Mladi na ljestvici odgovora od 7 stupnjeva $(1=$ nikada do $7=$ svakodnevno) odgovaraju samoiskazom koliko često igraju pojedinu igru.

U prikazu deskriptivnih rezultata korištena je međunarodno uvriježena kategorizacija učestalosti: 1 = nikada, 2 = ponekad, $3=$ redovito, pri čemu se pod redovitim kockanjem smatra ono koje se odvija jedanput tjedno ili češće od toga. Prilikom testiranja razlika u učestalosti kockanja korištena je originalna ljestvica odgovora od sedam stupnjeva.

\section{Subskala opće mjere ozbiljnosti problema povezanih s kockanjem (GPSS)}

GPSS subskala (eng. General Problem Severity Subscale) sastavni je dio CAGI instrumenta (eng. Canadian Adolescent Gambling Inventory), čiji su autori Tremblay, Stinchfield, Wiebe i Wynne (2010). Cjelokupni CAGI sastoji se od četiri faktora koji mjere različite skupine psihosocijalnih posljedica kockanja, dok je GPSS opća mjera ozbiljnosti problema povezanih s kockanjem, te se može koristiti i kao zasebna subskala.

GPSS se sastoji od 9 tvrdnji na koje mladi odgovaraju ljestvicom odgovora od četiri stupnja $(0=$ nikada, $1=$ ponekad, $2=$ većinu vremena, 3 = gotovo uvijek). Primjeri tvrdnji su: "Koliko često si se osjećao loše zbog načina na koji se kockaš ili onoga što se događa dok se kockaš?"; "Koliko često si se vraćao drugi dan kako bi pokušao vratiti novac izgubljen kockanjem?”. Računanjem ukupnog rezultata mogući teorijski raspon je od 0 do 27 bodova, a mladi se kategoriziraju u tri skupine ozbiljnosti razvijenih štetnih psihosocijalnih posljedica, koristeći metaforu sa semaforom prema sljedećim kriterijima:

(1) nepostojanje problema povezanih s kockanjem - zeleno svjetlo (0-1 bod)

(2) niska do srednja ozbiljnost problema žuto svjetlo (2-5 bodova) 
(3) visoka ozbiljnost problema - crveno svjetlo (6 i više bodova).

GPSS je do sada u hrvatskim istraživanjima pokazivao dobra metrijska svojstva, a u ovom istraživanju Cronbaachov alfa koeficijent pouzdanosti je $\alpha=, 88$.

\section{Upitnik percepcije industrije igara na sreću}

Pitanja o percepciji industrije igara na sreću usmjerena su na način na koji mladi vide tržište koje ih okružuje i koje im je dostupno, iako im kao maloljetnicima ne bi smjelo biti pristupačno. Ovaj dio upitnika sastoji se od niza pitanja o tome kako mladi percipiraju prisutnost mjesta koja nude igre na sreću u Hrvatskoj, kako procjenjuju zastupljenost prodajnih mjesta s obzirom na pristup maloljetnika igrama na sreću, kako procjenjuju mogućnost igranja maloljetnika, odnosno pristupačnost specifičnih igara na sreću maloljetnicima (lutrijske igre, sportsko klađenje, automati, igre u casinu, sportsko klađenje u kafićima na kladomatima te on-line pristup kockanju).

S obzirom na to da su, kao što je ranije navedeno, sve igre na sreću maloljetnicima zabranjene zakonskim izmjenama iz 2010. godine, mlade smo također pitali o njihovu mišljenju o minimalnoj dobi koja bi trebala biti legalna za uključivanje u pojedine igre na sreću.

\section{Postupak provedbe istraživanja}

Istraživanje je provedeno metodom papirolovka u srednjim školama (razredima) u Zagrebu i Splitu. Prije provedbe terenskog dijela istraživanja, projekt je dobio suglasnost Ministarstva znanosti, obrazovanja i sporta, te Etičkog povjerenstva Edukacijsko-rehabilitacijskog fakulteta Sveučilišta u Zagrebu. Učenici su ispunjavali upitnik u razredima, grupno, pri čemu je njihovo sudjelovanje bilo anonimno i dobrovoljno, a roditelji su na roditeljskom sastanku bili informirani o provedbi projekta u njihovoj školi, te su dali informirani prista- nak. Ispunjavanje je trajalo jedan školski sat. Istraživanje je u potpunosti provedeno u skladu s Etičkim kodeksom istraživanja s djecom (Ajduković i Kolesarić, 2003).

\section{Metode obrade podataka}

$\mathrm{Za}$ ostvarivanje ciljeva ovog istraživanja, uz deskriptivnu statistiku (frekvencije odgovora i mjere centralnih vrijednosti) i Spearmanov koeficijent korelacije, korištena je i inferencijalna statistika, točnije analiza varijance sa Scheffeovim post-hoc testom te KruskalWallisov test kao neparametrijska metoda, sa serijama Mann-Whitneyovih testova kao posthoc testova, uz računanje veličine efekta utvrđenih razlika po formuli $\mathrm{r}=\mathrm{Z} / \sqrt{ } \mathrm{N}$.

\section{REZULTATI I RASPRAVA}

\section{Učestalost kockanja srednjoškolaca s obzirom na ozbiljnost štetnih psihosocijalnih posljedica povezanih s kockanjem}

Kako je glavni cilj ovog istraživanja istražiti razlike u intenzitetu kockanja i percepciji hrvatskog tržišta mladih s obzirom na razinu razvijenih štetnih psihosocijalnih posljedica povezanih s kockanjem, nužno je bilo provjeriti zastupljenost pojedinih kategorija rizičnosti i eventualne dobne razlike između tri skupine mladića (zeleno svjetlo - žuto svjetlo crveno svjetlo). Rezultati u Tablici 1 pokazuju kako visokih 18,5\% mladića zadovoljava kriterije za "crveno svjetlo", njih 22,3\% za “žuto svjetlo" te da oko $60 \%$ muških srednjoškolaca nema nikakve štetne psihosocijalne posljedice kockanja. Vidljivo je da između srednjoškolaca nema dobnih razlika, odnosno da je prosječna dob svih triju skupina oko 16 godina. Takav rezultat u skladu je is ranijim hrvatskim 
Ricijaš, N., Mladi s problemima kockanja - koliko kockaju i kako vide industriju igara na sreću, Klinička psihologija 13 (2020), 1-2, 47-62

Tablica 1. Frekvencije zastupljenosti kategorizirane razine štetnih psihosocijalnih posljedica povezanih s kockanjem srednjoškolaca $(N=615)$ i razlike s obzirom na dob (ANOVA)

\begin{tabular}{lccccccc}
\hline $\begin{array}{l}\text { Kategorizacija } \\
\text { rizičnosti }\end{array}$ & $\mathrm{N}$ & $\%$ & $\mathrm{M}$ & $\mathrm{SD}$ & $\mathrm{F}$ & $\mathrm{df}$ & $\mathrm{p}$ \\
\hline Zeleno svjetlo & 364 & 59,2 & 16,15 & 1,96 & & & \\
Žuto svjetlo & 137 & 22,3 & 16,16 & 1,34 & 0,11 & 2 & $>, 050$ \\
Crveno svjetlo & 114 & 18,5 & 16,17 & 1,10 & & & \\
\hline Ukupno & 615 & 100,0 & & & & & \\
\hline
\end{tabular}

Legenda: $\mathrm{N}=$ apsolutni broj; \% = relativna frekvencija; $\mathrm{M}=$ aritmetička sredina; $\mathrm{SD}=$ standardna devijacija; F = F-omjer; $\mathrm{df}=$ stupnjevi slobode; $\mathrm{p}=$ statistička značajnost

istraživanjima (Ricijaš i sur., 2016), a omogućava nam da prilikom zaključivanja o razlikama u učestalosti kockanja s obzirom na razinu štetnih posljedica u skupini "crvenog svjetla" ne podrazumijevamo starije srednjoškolce, to jest one punoljetne, kojima je zakonom igranje igara na sreću i legalno dopušteno.

U Tablici 2 prikazani su rezultati o učestalosti kockanja mladih prema razini ozbiljnosti posljedica, dok se u Tablici 3 nalaze rezultati

Tablica 2. Učestalost kockanja srednjoškolaca $(N=615)$ prema kategorizaciji razvijenih štetnih psihosocijalnih posljedica povezanih s kockanjem (frekvencije odgovora)

\begin{tabular}{llccc}
\hline \multirow{2}{*}{ Vrsta igre } & Kategorija rizičnosti & $\begin{array}{c}\text { Nikada } \\
(\%)\end{array}$ & $\begin{array}{c}\text { Ponekad } \\
(\%)\end{array}$ & $\begin{array}{c}\text { Redovito } \\
(\%)\end{array}$ \\
\hline \multirow{3}{*}{ Loto } & Zeleno svjetlo & 71,1 & 27,1 & 1,7 \\
& Žuto svjetlo & 58,8 & 37,5 & 3,7 \\
& Crveno svjetlo & 38,2 & 46,4 & 15,5 \\
\hline \multirow{3}{*}{ Srećke } & Zeleno svjetlo & 61,2 & 37,7 & 1,1 \\
& Žuto svjetlo & 56,6 & 42,6 & 0,7 \\
& Crveno svjetlo & 37,0 & 56,5 & 6,5 \\
\hline \multirow{3}{*}{ Sportsko klađenje } & Zeleno svjetlo & 62,6 & 33,0 & 4,4 \\
& Žuto svjetlo & 18,5 & 48,9 & 32,6 \\
& Crveno svjetlo & 3,7 & 22,2 & 74,1 \\
\hline \multirow{3}{*}{ Igre na automatima } & Zeleno svjetlo & 81,4 & 16,1 & 2,5 \\
& Žuto svjetlo & 54,8 & 37,8 & 7,4 \\
& Crveno svjetlo & 31,2 & 33,0 & 35,8 \\
\hline \multirow{3}{*}{ Kasino igre } & Zeleno svjetlo & 92,0 & 7,2 & 0,8 \\
& Žuto svjetlo & 83,1 & 16,2 & 0,7 \\
& Crveno svjetlo & 66,4 & 23,6 & 10,0 \\
\hline \multirow{2}{*}{ Kartanje s prijateljima za novac } & Žuto svjetlo & 73,6 & 24,8 & 1,7 \\
& Crveno svjetlo & 33,0 & 30,9 & 2,9 \\
& & & 43,1 & 23,9 \\
\hline
\end{tabular}


Tablica 3. Razlike u učestalosti kockanja srednjoškolaca $(\mathrm{N}=615)$ s obzirom na razinu štetnih psihosocijalnih posljedica povezanih s kockanjem (Kruskal-Wallisov test s Mann-Whitneyevim post-hoc testom)

\begin{tabular}{|c|c|c|c|c|c|c|c|}
\hline Vrsta igre & $\begin{array}{l}\text { Kategorija } \\
\text { rizičnosti }\end{array}$ & MR & $\chi^{2}$ & $\mathrm{df}$ & $\mathrm{p}$ & $\begin{array}{c}\mathrm{M}-\mathrm{W} \\
\text { post-hoc }\end{array}$ & $\mathrm{r}$ \\
\hline \multirow{3}{*}{ Loto } & Zeleno svjetlo & 272,93 & \multirow{3}{*}{55,91} & \multirow{3}{*}{2} & \multirow{3}{*}{$<, 001$} & \multirow{3}{*}{$\begin{array}{l}\mathrm{Z}<\check{Z} \\
\mathrm{Z}<\mathrm{C} \\
\check{Z}<\mathrm{C}\end{array}$} & \multirow{3}{*}{$\begin{array}{l}, 13 \\
, 34 \\
, 24\end{array}$} \\
\hline & Žuto svjetlo & 317,21 & & & & & \\
\hline & Crveno svjetlo & 395,75 & & & & & \\
\hline \multirow{3}{*}{ Srećke } & Zeleno svjetlo & 282,72 & \multirow{3}{*}{27,95} & \multirow{3}{*}{2} & \multirow{3}{*}{$<, 001$} & \multirow{3}{*}{$\begin{array}{l}Z<C \\
Z ̌ Z<C\end{array}$} & \multirow{3}{*}{$\begin{array}{l}, 24 \\
, 21\end{array}$} \\
\hline & Žuto svjetlo & 305,11 & & & & & \\
\hline & Crveno svjetlo & 374,12 & & & & & \\
\hline \multirow{3}{*}{ Sportsko klađenje } & Zeleno svjetlo & 217,96 & \multirow{3}{*}{260,17} & \multirow{3}{*}{2} & \multirow{3}{*}{$<, 001$} & \multirow{3}{*}{$\begin{array}{l}\mathrm{Z}<\check{Z} \\
\mathrm{Z}<\mathrm{C} \\
\check{Z}<\mathrm{C}\end{array}$} & \multirow{3}{*}{$\begin{array}{l}, 46 \\
, 66 \\
, 47 \\
\end{array}$} \\
\hline & Žuto svjetlo & 374,94 & & & & & \\
\hline & Crveno svjetlo & 494,52 & & & & & \\
\hline \multirow{3}{*}{ Igre na automatima } & Zeleno svjetlo & 251,19 & \multirow{3}{*}{135,65} & \multirow{3}{*}{2} & \multirow{3}{*}{$<, 001$} & \multirow{3}{*}{$\begin{array}{l}Z<\check{Z} \\
Z<C \\
\check{Z}<C\end{array}$} & \multirow{3}{*}{$\begin{array}{l}, 29 \\
, 52 \\
, 33\end{array}$} \\
\hline & Žuto svjetlo & 334,86 & & & & & \\
\hline & Crveno svjetlo & 341,90 & & & & & \\
\hline \multirow{3}{*}{ Casino igre } & Zeleno svjetlo & 384,03 & \multirow{3}{*}{48,65} & \multirow{3}{*}{2} & \multirow{3}{*}{$<, 001$} & \multirow{3}{*}{$\begin{array}{l}Z<\check{Z} \\
Z<C \\
\check{Z}<C\end{array}$} & \multirow{3}{*}{$\begin{array}{l}, 13 \\
, 32 \\
, 20\end{array}$} \\
\hline & Žuto svjetlo & 312,11 & & & & & \\
\hline & Crveno svjetlo & 365,41 & & & & & \\
\hline \multirow{3}{*}{$\begin{array}{l}\text { Kartanje s prijateljima } \\
\text { za novac }\end{array}$} & Zeleno svjetlo & 271,93 & \multirow{3}{*}{80,14} & \multirow{3}{*}{2} & \multirow{3}{*}{$<, 001$} & \multirow{3}{*}{$\begin{array}{l}Z<\check{Z} \\
Z<C \\
\check{Z}<C\end{array}$} & \multirow{3}{*}{$\begin{array}{l}, 09 \\
, 41 \\
, 36\end{array}$} \\
\hline & Žuto svjetlo & 300,33 & & & & & \\
\hline & Crveno svjetlo & 418,17 & & & & & \\
\hline
\end{tabular}

Legenda: $\mathrm{MR}=$ prosječni rang; $\chi^{2}=$ hi-kvadrat; $\mathrm{df}=$ stupnjevi slobode; $\mathrm{p}=$ statistička značajnost; $\mathrm{M}-\mathrm{W}$ post-hoc $=$ Mann-Whitney test kao post-hoc test; $\mathrm{r}=$ veličina efekta

testiranja razlika u učestalosti kockanja s obzirom na kategorizaciju posljedica. Vidljivo je da na svim ispitivanim igrama na sreću postoji značajna razlika u učestalosti kockanja srednjoškolaca s obzirom na razinu ozbiljnosti posljedica. Mladi koji imaju ozbiljnu razinu štetnih psihosocijalnih posljedica kockaju značajno češće od drugih skupina mladih, a efekti razlika posebno su značajni kod sportskog klađenja i igara na automatima. Također je provjerena Spearmanova inter-korelacija učestalosti kockanja različitih igara, te su sve inter-korelacije pozitivne i značajne, pri čemu se kreću od niskih $\mathrm{r}=, 174$ (srećke i igre u ca$\operatorname{sinu}$ ) do visokih $\mathrm{r}=, 619$ (igre klađenja i igre na automatima). To znači da mladi koji se uče- stalo klade, često igraju i igre na automatima, te učestalost kockanja na ove dvije igre dijeli oko $38 \%$ zajedničke varijance.

Oko 75\% mladih koji zadovoljavaju kriterije za "crveno svjetlo" redovito se kladi (jedanput tjedno ili češće od toga), dok oko $35 \%$ njih redovito sudjeluje u igrama na automatima. U usporedbi s mladima koji zadovoljavaju kriterije za zeleno i žuto svjetlo, to je značajno više, te zabrinjavajuće u kontekstu pristupačnosti igara na sreću maloljetnicima. Posebno je potrebno prikazane rezultate promatrati kroz visok i vrlo visok adiktivni potencijal, odnosno rizičnost sportskog klađenja i igara na automatima (Binde, Rodmil i Volberg, 2017), što se posredno potvrđuje i ovim rezultatima, 
Ricijaš, N., Mladi s problemima kockanja - koliko kockaju i kako vide industriju igara na sreću, Klinička psihologija 13 (2020), 1-2, 47-62

budući da su efekti razlika upravo u ove dvije igre najznačajniji $(, 29<\mathrm{r}<, 66)$.

\section{Percepcija industrije igara na sreću srednjoškolaca s obzirom na ozbiljnost štetnih psihosocijalnih posljedica povezanih $s$ kockanjem}

Visoka dostupnost, odnosno prisutnost igara na sreću u Hrvatskoj sastavni je dio današnjeg tržišta igara na sreću, o kojem je bilo više riječi u uvodnom dijelu. Međutim, to kako mladi vide dostupnost, a posljedično i pristupačnost igara na sreću maloljetnicima, od posebnog je interesa ovog istraživanja. Iz rezultata uočavamo da gotovo $83 \%$ srednjoškolaca smatra da su mjesta koja nude igre na sreću u Hrvatskoj prilično ili izrazito prisutna, te da svega $7 \%$ srednjoškolaca procjenjuje da maloljetnici ne mogu pristupiti igrama na sreću. Uistinu je zabrinjavajući podatak da 93\% učenika procjenjuje kako maloljetnici mogu pristupiti igrama na sreću, od čega 50\% njih navodi da je to moguće na većini prodajnih mjesta, a 21,3\% na gotovo svim prodajnim mjestima. Pritom mladići iz Splita, u odnosu na one iz Zagreba, nešto više percipiraju igre na sreću prisutnima (MWU $=40$ 026; p < ,050; $\mathrm{r}=, 16)$, te nešto pristupačnijima maloljetnicima (MWU $=37$ 261; $\mathrm{p}<, 010 ; \mathrm{r}=$ ,20), ali efekti tih razlika nisu veliki.

U odnosu na pristupačnost pojedinim igrama, percepcija mladih odgovara i određenim objektivnim aspektima realiteta, odnosno sukladna je rezultatima dosadašnjih istraživanja na našim prostorima o učestalosti kockanja mladih (Dodig i Ricijaš, 2011; Bijedić i sur., 2015; Ricijaš, Dodig Hundrić i Kranželić, 2015; Puharić i sur., 2016; Ricijaš i sur., 2016; Mikas, Šimić i Rajič, 2019; Peroš, 2019; Ricijaš i Dodig Hundrić, 2019), što govori u prilog plauzibilnosti rezultata i iz ove perspektive. Pristup specifičnim igrama mjerio se ljestvicom odgovora od 5 stupnjeva, od

Tablica 4. Percepcija industrije igara na sreću srednjoškolaca $(\mathrm{N}=615)$ (frekvencije odgovora)

\begin{tabular}{|c|c|c|c|c|c|c|}
\hline \multicolumn{7}{|c|}{ Prema tvojem mišljenju, koliko su mjesta koja nude igre na sreću prisutna u Hrvatskoj? } \\
\hline Slabo su prisutna & \multicolumn{2}{|c|}{ Umjereno su prisutna } & \multicolumn{2}{|c|}{ Prilično su prisutna } & \multicolumn{2}{|c|}{ Izrazito su prisutna } \\
\hline $4,2 \%$ & \multicolumn{2}{|c|}{$13,0 \%$} & \multicolumn{2}{|c|}{$45,3 \%$} & \multicolumn{2}{|c|}{$37,6 \%$} \\
\hline \multicolumn{7}{|c|}{ Kako procjenjuješ pristup maloljetnika igrama na sreću u Hrvatskoj (mogućnost igranja)? } \\
\hline Ne mogu im pristupiti & \multicolumn{2}{|c|}{$\begin{array}{c}\text { Samo na rijetkim } \\
\text { mjestima im mogu } \\
\text { pristupiti }\end{array}$} & \multicolumn{2}{|c|}{$\begin{array}{l}\text { Na većini prodajnih } \\
\text { mjesta im mogu } \\
\text { pristupiti }\end{array}$} & \multicolumn{2}{|c|}{$\begin{array}{c}\text { Na gotovo svim } \\
\text { prodajnim mjestima im } \\
\text { mogu pristupiti }\end{array}$} \\
\hline $7,0 \%$ & \multicolumn{2}{|c|}{$21,8 \%$} & \multicolumn{2}{|c|}{$50,0 \%$} & \multicolumn{2}{|c|}{$21,3 \%$} \\
\hline \multicolumn{7}{|c|}{ Kako procjenjuješ pristup i mogućnost maloljetnika da igraju sljedeće igre na sreću u Hrvatskoj? } \\
\hline \multicolumn{3}{|r|}{$\begin{array}{l}\text { Uopće im } \\
\text { ne mogu } \\
\text { pristupiti }\end{array}$} & \multicolumn{2}{|c|}{$\begin{array}{l}\text { Jako teško } \\
\text { im mogu pristupiti }\end{array}$} & \multicolumn{2}{|c|}{$\begin{array}{l}\text { Jako lako } \\
\text { im mogu pristupiti }\end{array}$} \\
\hline Lutrijske igre & & $9,0 \%$ & $17,2 \%$ & $23,1 \%$ & $24,4 \%$ & $26,4 \%$ \\
\hline Igre klađenja & & $3,7 \%$ & $3,9 \%$ & $5,2 \%$ & $24,7 \%$ & $62,5 \%$ \\
\hline Igre na automatima & & $6,7 \%$ & $8,5 \%$ & $14,7 \%$ & $25,5 \%$ & $44,6 \%$ \\
\hline Igre u casinima & & $23,7 \%$ & $26,0 \%$ & $23,5 \%$ & $26,2 \%$ & $10,6 \%$ \\
\hline Klađenje na kladomatim & kafiću & $3,6 \%$ & $3,3 \%$ & $5,5 \%$ & $16,4 \%$ & $71,2 \%$ \\
\hline Online kockanje & & $6,8 \%$ & $7,7 \%$ & $9,0 \%$ & $19,1 \%$ & $57,5 \%$ \\
\hline
\end{tabular}


$1=$ uopće im ne mogu pristupiti do $5=$ jako lako im mogu pristupiti. U ovom aspektu, posebno je zabrinjavajući podatak da preko $60 \%$ srednjoškolaca procjenjuje da se igrama klađenja jako lako može pristupiti, odnosno preko 70\% njih smatra da se klađenju na kladomatima (samoposlužnim terminalima) u kafićima jako lako može pristupiti (pri čemu mladići iz Splita nešto više od zagrebačkih srednjoškolaca; MWU = 43 938; $<<, 010 ; \mathrm{r}=, 20)$.
Iz rezultata uočavamo da su srednjoškolci svjesni da je igrama u casinu nemoguće ili najteže pristupiti, pri čemu moramo voditi računa da u Hrvatskoj i među građanima, ali i u stručnoj javnosti, često postoji nerazumijevanje razlika između casina i automat klubova, s obzirom na to da automat klubovi nude sve casino igre (primjerice rulet, igre na kartama i sl.), ali na automatima (bez croupiera). Medutim, kontrola identiteta na ulazu potpuno

Tablica 5. Razlike u percepciji industrije igara na sreću srednjoškolaca s obzirom na razinu štetnih psihosocijalnih posljedica povezanih s kockanjem $(\mathrm{N}=615)$ (Kruskal-Wallisov test s Mann-Whitneyevim post-hoc testom)

\begin{tabular}{|c|c|c|c|c|c|c|c|}
\hline Varijabla & $\begin{array}{l}\text { Kategorija } \\
\text { rizičnosti }\end{array}$ & MR & $\chi^{2}$ & $\mathrm{df}$ & $\mathrm{p}$ & $\begin{array}{c}\mathrm{M}-\mathrm{W} \\
\text { post-hoc }\end{array}$ & $\mathrm{r}$ \\
\hline \multirow{3}{*}{$\begin{array}{l}\text { Procjena prisutnosti igara } \\
\text { na sreću u RH }\end{array}$} & Zeleno svjetlo & 281,76 & & & & & \\
\hline & Žuto svjetlo & 339,61 & 12,89 & 2 & $<, 010$ & $\mathrm{Z}<\check{\mathrm{Z}}$ & ,16 \\
\hline & Crveno svjetlo & 306,73 & & & & & \\
\hline \multirow{3}{*}{$\begin{array}{l}\text { Procjena pristupačnosti } \\
\text { maloljetnika igrama na } \\
\text { sreću }\end{array}$} & Zeleno svjetlo & 289,16 & & & & & \\
\hline & Žuto svjetlo & 293,97 & 0,54 & 2 & $<, 050$ & & \\
\hline & Crveno svjetlo & 301,56 & & & & & \\
\hline \multirow{3}{*}{ Pristup lutrijskim igrama } & Zeleno svjetlo & 301,66 & & & & & \\
\hline & Žuto svjetlo & 287,75 & 4,07 & 2 & $>, 050$ & & \\
\hline & Crveno svjetlo & 330,98 & & & & & \\
\hline \multirow{3}{*}{ Pristup igrama klađenja } & Zeleno svjetlo & 291,40 & & & & & \\
\hline & Žuto svjetlo & 331,60 & 8,86 & 2 & $<, 050$ & $\begin{array}{l}\mathrm{Z}<\mathrm{Z} \\
\mathrm{Z}<\mathrm{C}\end{array}$ & $\begin{array}{l}, 11 \\
09\end{array}$ \\
\hline & Crveno svjetlo & 324,85 & & & & & \\
\hline \multirow{3}{*}{$\begin{array}{l}\text { Pristup igrama na } \\
\text { automatima }\end{array}$} & Zeleno svjetlo & 286,85 & & & & & \\
\hline & Žuto svjetlo & 333,57 & 10,06 & 2 & $<, 010$ & $\begin{array}{l}\mathrm{Z}<\mathrm{Z} \\
\mathrm{Z}<\mathrm{C}\end{array}$ & $\begin{array}{l}, 12 \\
09\end{array}$ \\
\hline & Crveno svjetlo & 325,64 & & & & & \\
\hline \multirow{3}{*}{ Pristup casino igrama } & Zeleno svjetlo & 297,31 & & & & & \\
\hline & Žuto svjetlo & 309,48 & 1,86 & 2 & $>, 050$ & & \\
\hline & Crveno svjetlo & 321,45 & & & & & \\
\hline \multirow{3}{*}{$\begin{array}{l}\text { Pristup kladomatima u } \\
\text { kafićima }\end{array}$} & Zeleno svjetlo & 283,43 & & & & & \\
\hline & Žuto svjetlo & 340,09 & 21,99 & 2 & $<001$ & $\begin{array}{l}\mathrm{Z}<\mathrm{Z} \\
\mathrm{Z}<\mathrm{C}\end{array}$ & $\begin{array}{l}, 17 \\
14\end{array}$ \\
\hline & Crveno svjetlo & 334,88 & & & & & \\
\hline \multirow{3}{*}{ Pristup online kockanju } & Zeleno svjetlo & 309,49 & & & & & \\
\hline & Žuto svjetlo & 292,47 & 1,18 & 2 & $>, 050$ & & \\
\hline & Crveno svjetlo & 308,30 & & & & & \\
\hline
\end{tabular}

Legenda: $\mathrm{MR}=$ prosječni rang; $\chi^{2}=$ hi-kvadrat; $\mathrm{df}=$ stupnjevi slobode; $\mathrm{p}=$ statistička značajnost; $\mathrm{M}-\mathrm{W}$ post-hoc $=$ Mann-Whitney test kao post-hoc test; $\mathrm{r}=$ veličina efekta 
Ricijaš, N., Mladi s problemima kockanja - koliko kockaju i kako vide industriju igara na sreću, Klinička psihologija 13 (2020), 1-2, 47-62

je različita. Pravilnik o prostornim i tehničkim uvjetima za priređivanje igara na sreću u casinima, na automatima i uplatnim mjestima kladionica (NN 38/2010, 130/2010, 69/2011, $15 / 2012,151 / 2014$ ) propisuje da se za ulazak u prostor casina treba registrirati i provjeriti dob/punoljetnost posjetitelja, dok za automat klubove takva odredba ne postoji. Stoga je i maloljetnicima puno jednostavnije pristupiti automat klubovima, u kojima mogu igrati i igre karakteristične za casino.

U Tablici 5 prikazane su testirane razlike u percepciji dostupnosti i pristupačnosti igara na sreću maloljetnicima s obzirom na razinu razvijenih štetnih psihosocijalnih posljedica povezanih s kockanjem. Rezultati pokazuju određene, iako ne velike, razlike među srednjoškolcima, i to u očekivanom smjeru. Generalno, mladi koji nemaju probleme povezane s kockanjem (zeleno svjetlo) u nešto manjoj mjeri procjenjuju prisutnost igara na sreću u Hrvatskoj, te mogućnost pristupa igrama kla- đenja, igrama na automatima i klađenju na kladomatima (samoposlužnim terminalima) u kafićima. Ovakav rezultat moguće je interpretirati i u skladu s heuristikom dostupnosti u kognitivnoj psihologiji (Aronson, Wilson i Akert, 2005:74-76) i udešavanjem koje utječe na dostupnost neke sheme, osobina ili pojma (Higgins, 1996). S druge pak strane, istraživanja potvrđuju pozitivnu povezanost između dostupnosti i pristupačnosti igara na sreću te učestalosti konzumacije, iako ta priroda nije u potpunosti linearna (Marshall, 2005; StPierre, Walker, Derevenski i Gupta, 2014).

Kako bismo istražili određeni odnos prema igrama na sreću i njihovoj konzumaciji, pitali smo srednjoškolce što misle koja bi trebala biti minimalna dob za uključivanje u pojedine igre na sreću u Hrvatskoj. Rezultati analize varijance (Tablica 6) pokazuju značajne razlike na svim igrama, $i$ to ujednačeno u istom smjeru s obzirom na kategorizaciju rizičnosti. Mladi koji nemaju štetne psihosocijalne posljedi-

Tablica 6. Razlike u percepciji potrebne dobi za uključivanje u pojedine igre na sreću srednjoškolaca $(\mathrm{N}=615)$ s obzirom na razinu štetnih psihosocijalnih posljedica povezanih s kockanjem

\begin{tabular}{|c|c|c|c|c|c|c|c|c|}
\hline Vrsta igre & $\begin{array}{l}\text { Kategorija } \\
\text { rizičnosti }\end{array}$ & M & SD & $\mathrm{F}$ & $\mathrm{df}$ & $\mathrm{p}$ & $\begin{array}{c}\mathrm{SCH} \\
\text { post-hoc }\end{array}$ & $\mathrm{p}$ \\
\hline \multirow{3}{*}{ Lutrijske igre } & Zeleno svjetlo & 17,70 & 1,67 & \multirow{3}{*}{22,01} & \multirow{3}{*}{2} & \multirow{3}{*}{$<, 001$} & $Z>Z ̌ Z$ & $<, 050$ \\
\hline & Žuto svjetlo & 17,23 & 1,79 & & & & $\mathrm{Z}>\mathrm{C}$ & $<, 001$ \\
\hline & Crveno svjetlo & 16,45 & 1,86 & & & & $\mathrm{Z}>\mathrm{C}$ & $<, 010$ \\
\hline \multirow{3}{*}{ Igre klađenja } & Zeleno svjetlo & 17,88 & 1,73 & \multirow{3}{*}{67,40} & \multirow{3}{*}{2} & \multirow{3}{*}{$<, 001$} & $Z>Z ̌$ & $<, 001$ \\
\hline & Žuto svjetlo & 17,06 & 1,81 & & & & $Z>C$ & $<, 001$ \\
\hline & Crveno svjetlo & 15,73 & 1,62 & & & & $\mathrm{Z}>\mathrm{C}$ & $<, 001$ \\
\hline \multirow{3}{*}{ Igre u casinima } & Zeleno svjetlo & 19,02 & 1,62 & \multirow{3}{*}{33,18} & \multirow{3}{*}{2} & \multirow{3}{*}{$<, 001$} & & \multirow{3}{*}{$\begin{array}{l}<, 001 \\
<, 001\end{array}$} \\
\hline & Žuto svjetlo & 18,70 & 1,84 & & & & $\begin{array}{l}Z>C \\
Z Z>C\end{array}$ & \\
\hline & Crveno svjetlo & 17,46 & 2,06 & & & & & \\
\hline \multirow{3}{*}{ Igre na automatima } & Zeleno svjetlo & 18,38 & 1,76 & \multirow{3}{*}{35,98} & \multirow{3}{*}{2} & \multirow{3}{*}{$<, 001$} & $Z>\check{Z}$ & $<, 001$ \\
\hline & Žuto svjetlo & 17,65 & 2,01 & & & & $Z>C$ & $<, 001$ \\
\hline & Crveno svjetlo & 16,68 & 2,09 & & & & タ̌ & $<, 001$ \\
\hline
\end{tabular}

Legenda: $\mathrm{M}=$ aritmetička sredina; $\mathrm{SD}=$ standardna devijacija; $\mathrm{F}=\mathrm{F}$-omjer; $\mathrm{df}=$ stupnjevi slobode; $\mathrm{p}$ $=$ statistička značajnost, $\mathrm{SCH}$ post-hoc $=\mathrm{Scheffeov}$ post - hoc test 
ce, u odnosu na one koji imaju, dominantno smatraju da bi država trebala regulirati višu minimalnu dob za uključivanje u igre na sreću. Za većinu igara to je između 17 i 18 godina, a za igre u casinima prosječno 19 godina života, što posredno također govori u prilog razumijevanju različitog adiktivnog potencijala tih igara i kod mladih. S druge pak strane, prosječna dob koju mladi s ozbiljnim problemima povezanih s kockanjem smatraju nužnom za uključivanje u kockanje je manja od 18 godina za sve igre. Štoviše, najmanja je upravo za igre sportskog klađenja i iznosi $\mathrm{M}=15,73$, što dodatno govori u prilog atraktivnosti ove igre i nerazumijevanja njezine rizičnosti i adiktivnosti od strane mladih s razvijenim problemima. Ovakav rezultat moguće je usporediti i s rezultatima inozemnih istraživanja koji govore u prilog pozitivnijim stavovima prema kockaju kod osoba koje su razvile probleme (Jacobs, 2000; Chiu i Storm, 2010) i s Teorijom razložne akcije koja pozitivne stavove prema kockanju te subjektivne norme dovodi u vezu s predviđanjem namjere za kockanjem (Moore i Ohtsuka, 1997; Thrasher, Andrew i Mahony, 2007).

\section{ZAKLJUČAK}

Ovo istraživanje bavi se kockanjem srednjoškolaca kao rizičnim ponašanjem koje je u Hrvatskoj i u većini drugih zemalja zapadnog svijeta maloljetnicima geografski dostupno, ali zakonom zabranjeno te im stoga ne bi trebalo biti pristupačno. Ipak, brojni svjetski znanstvenici istražuju kockanje adolescenata svjesni činjenice da su ove aktivnosti njima, iako zakonski zabranjene, pristupačne, slično kao što je slučaj s konzumacijom duhanskih proizvoda i alkoholnih pića. Mladi, posebno mladići, su i rizičnija, odnosno ranjivija skupina za razvoj ovisnosti o kockanju (Dowling, Merkouris, Greenwood, Oldenhof, Toum- bourou i Youssef, 2017; Buth, Wurst, Thon, Lahusen i Kalke, 2017; Sharman, Butler i Roberts, 2019), stoga ne čudi i visoka prevalencija problema povezanih s kockanjem u populaciji muških srednjoškolaca. Valja naglasiti da rezultatima ovog istraživanja nisu potvrđene dobne razlike između maloljetnika s obzirom na razinu štetnih psihosocijalnih posljedica kockanja. Međutim, dobivene su značajne razlike u učestalosti kockanja i percepciji industrije igara na sreću. Činjenica da mladi s razvijenim štetnim posljedicama učestalije igraju rizičnije igre dodatno govori u prilog njihovu adiktivnom potencijalu. Također, kod mladih uočavamo i svjesnost o okruženju u kojemu žive na način da srednjoškolci igre na sreću percipiraju vrlo dostupnima u našem društvu i pristupačnim maloljetnicima. Činjenica da mladi s razvijenim problemima percipiraju kockarske mogućnosti prisutnijima, a specifične visokorizične igre i pristupačnijima, dodatno govori u prilog nepovoljnim uvjerenjima koja se kod mladih, na temelju iskustva kockanja, stvaraju. Istovremeno, oni smatraju i da bi značajno niža dob trebala biti legalna za uključivanje u pojedine igre na sreću, posebno sportsko klađenje, što dodatno potkrepljuje zaključke o normalizaciji ovog rizičnog ponašanja i nerazumijevanje adiktivnih obilježja igara na sreću.

Rezultati nedvojbeno govore u prilog potrebi za kontinuiranim preventivnim aktivnostima usmjerenim prema kockanju mladih, kako provedbom univerzalnih preventivnih programa (Huić, Kranželić, Dodig Hundrić i Ricijaš, 2017), tako i širim društvenim preventivnim strategijama usmjerenim prema smanjivanju dostupnosti i pristupačnosti, kvalitetnijem reguliranju tržišta igara na sreću, postavljanju standarda oglašavanja igara na sreću i slično (Ricijaš, Maglica i Dodig Hundrić, u tisku). S druge pak strane, visoka prevalencija mladih s problemima kockanja logično nameće zaključke i o potrebi razvoja specifičnih 
Ricijaš, N., Mladi s problemima kockanja - koliko kockaju i kako vide industriju igara na sreću, Klinička psihologija 13 (2020), 1-2, 47-62

tretmanskih intervencija prema mladima koje na našim prostorima ne postoje.

\section{LITERATURA}

Abbott, M. W. (2007). Situational factors that affect gambling behaviour. U G. Smith, D. C. Hodgins, \& R. J. Williams (ur.), Research and measurement issues in gambling studies (251278). Burlington, MA: Academic Press.

Abbott, M., Volberg, R., Bellringer, M. i Reith, G. (2004). A Review of Research on Aspects of Problem Gambling - Final Report. London: Responsibility in Gambling Trust

Ajduković, M., Kolesarić, I. (2003). Etički kodeks istraživanja s djecom. Zagreb: Državni zavod za zaštitu obitelji, materinstva i mladeži.

Andrie, E. K., Tzavara, C. K., Tzavela, E., Richardson, C., Greydanus, D., Tsolia, M. i Tsitsika, A. K. (2019). Gambling involvement and problem gambling correlates among European adolescents: results from the European Network for Addictive Behavior study. Social Psychiatry and Psychiatric Epidemiology, 54. 1429-1441. DOI: https://doi.org/10.1007/ s00127-019-01706-w

Aronson, E., Wilson, T. D. i Akert, R. M. (2005). Socijalna psihologija. Četvrto izdanje. Zagreb: Mate d.o.o.

Bijedić, M., Kuralić-Čišić, L., Kovačević, R. i Vardo, E. (2015). Navike kockanja srednjoškolaca $\mathrm{u}$ dvije urbane sredine u Bosni i Hercegovini. Socijalne teme, 1(2), 43-65.

Binde, P., Romild, U. i Volberg, R. A. (2017). Forms of gambling, gambling involvement and problem gambling: evidence from a Swedish population survey. International Gambling Studies, 17(3) 490-507. DOI: https://doi.org/10.10 80/14459795.2017.1360928

Buth S., Wurst F. M., Thon N., Lahusen H. i Kalke J. (2017). Comparative Analysis of Potential Risk Factors for at-Risk Gambling, Problem Gambling and Gambling Disorder among $\mathrm{Cu}-$ rrent Gamblers - Results of the Austrian Representative Survey 2015. Frontiers in Psychology, 8(2188). DOI: 10.3389/fpsyg.2017.02188.
Calado, F., Alexandre, J. i Griffiths, M. D. (2017). Prevalence of Adolescent Problem Gambling: A systematic Review of Recent Research. Journal of Gambling Studies, 33, 397-424. doi:10.1007/s10899-016-9627-5.

Carran, M. (2018). Consumer Protection in EU Online Gambling Regulation - Review of the implementation of selected provision of European Union Commission Recommendation 2014/478/EU accross EU States. https://www. egba.eu/uploads/2018/12/181206-ConsumerProtection-in-EU-Online-Gambling-EBGAReport-December-2018.pdf

Castren, S., Grainger, M., Lahti, T., Alho, H i Salonen, A. H. (2015). At-risk and problem gambling among adolescents: a convenience sample of first-year junior high school students in Finland. Substance Abuse Treatment, Prevention, and Policy, 10(9), 1-10. DOI 10.1186/ s13011-015-0003-8

Chiu, J. i Storm, L. (2010). Personality, Peerceived Luck and Gambling Attitudes as Predictors of Gambling Involvement. Journal of Gambling Studies, 26, 205-227. DOI: 10.1007/s10899009-9160-x

de Luigi, M., Gibertoni, D., Randon, E. i Scorcu, A. E. (2017). Patterns of Gambling Activities and Gambling Problems Among Italian High School Students: Results from a Latent Class Analysis. Journal of Gambling Studies, 34(2). 339-359. DOI: 10.1007/s10899-017-9694-2.

Delfabbro, P., Lahn, J. i Grabosky, P. (2006). Psychosocial Correlates of Problem Gambling in Australian Students. Australian and New Zealand Journal of Psychiatry, 40, 587-595. DOI: 10.1080/j.1440-1614.2006.01843.x.

Dodig, D. (2013). Izazovi procjene i odrednice izraženosti psihosocijalnih posljedica kockanja adolescenata. Kriminologija i socijalna integracija, 21(2), 1-14.

Dodig, D., Ricijaš, N. (2011). Obilježja kockanja zagrebačkih adolescenata. Ljetopis socijalnog rada, 18(1), 103-125.

Dowling, N. A., Merkouris, S. S., Greenwood, C. J., Oldenhof, E., Toumbourou, J. W. i Youssef, G. J. (2017). Early risk and protective factors for problem gambling: A systematic review and meta-analysis of longitudinal studies. Clinical Psychology Review, 51, 109-124. DOI: https://doi.org/10.1016/j.cpr.2016.10.008 
Europska Komisija (2012). Online Gambling in the Internal Market. Commission Staff Working Document.

Glavak Tkalić, R. i Miletić, G. M. (2012). Igranje igara na sreću u općoj populaciji Republike Hrvatske: Istraživačko izvješće. Zagreb: Institut društvenih znanosti Ivo Pilar.

Glavak Tkalić, R., Miletić, G. M. i Sučić, I. (2017). Igranje igara na sreću u hrvatskom društvu. Zagreb: Institut društvenih znanosti Ivo Pilar i Ured za suzbijanje zlouporabe droga Vlade Republike Hrvatske.

Hardoon, K. K. i Derevensky, J. L. (2002). Child and Adolescent Gambling Behavior: $\mathrm{Cu}-$ rrent Knowledge. Clinical Child Psychology and Psychiatry, 7(2), 263-281. DOI: $10.1177 / 1359104502007002012$.

Higgins, E. T. (1996). Knowledge Activation: Accessibility, Accessibility, Applicability, and Salience. U Higgins, E. T., Kruglanski, A. W. (ur), Social Psychology: Handbook of Basic Principles. New York: The Guilford Press.

Huić, A., Kranželić, V., Dodig Hundrić, D. i Ricijaš, N. (2017). Who Really Wins? Efficacy of Croatian Youth Gambling Prevention Program. Journal of Gambling Studies, 33, 1011-1033. DOI 10.1007/s10899-017-9668-4

Jacobs, D. F. (2000). Juvenile Gambling in North America: An Analysis of Long Term Trends and Future Prospects. Journal of Gambling Studies, 16, 119-152. DOI: 10.1023/A:1009476829902.

Livazović, G. i Bojčić, K. (2017). Povezanost sociodemografskih obilježja, rizičnih stilova ponašanja i sklonosti kockanju adolescenata. Život $i$ škola: časopis za teoriju i praksu odgoja $i$ obrazovanja, 63, 137-150.

Livazović, G. i Bojčić, K. (2019). Problem gambling in adolescents: what are the psychological, social and financial consequences? BMC Psychiatry, 19(308). DOI: https://doi.org/10.1186/ s12888-019-2293-2.

Marshall, D. (2005). The Gambling Environment and Gambler Behaviour: Evidence from Richmond-Tweed, Australia. International Gambling Studies, 5(1), 63-83. DOI: 10.1080/14459790500099471.

Mikas, D., Šimić, K. i Rajič, I. (2019). Kockanje - Zabava ili opasna ovisnost? Zbornik Odseka za pedagogiju, 28, 111-135. DOI: https://doi. org/10.19090/zop.2019.28.111-136.

Molinaro, S., Benedetti, E., Scalese, M., Bastiani, L., Fortunato, L., Cerrai, S., Chomynova, P., Elekes, Z., Feijao, F., Fotiou, A., Kokkevi, A., Kraus, L., Rupšiene, L., Monshouwer, K., Nociar, A., Strizek, J. i Urdih Lazar, T. (2018). Prevalence of youth gambling and potential infulence of substance use and other risk factors throughout 33 European countries: first results from the 2015 ESPAD study. Addiction, 113(10), 1862-1872. DOI: 10.1111/ add. 14275 .

Moore, M. S. i Ohtsuka, K. (1997). Gambling Activities Among Young Australians: Developing a model of behavior. Journal of Gambling Studies, 13(3), 207-236. DOI: 10.1023/a:1024979232287

Peroš, D. (2019). Obilježja kockanja mladića grada Zadra - učestalost kockanja, zastupljenost problema i povezanost s problematičnom uporabom interneta. Diplomski rad. Zagreb: Edukacijsko-rehabilitacijski fakultet Sveučilišta u Zagrebu

Pravilnik o prostornim i tehničkim uvjetima za priređivanje igara na sreću u casinima, na automatima i uplatnim mjestima kladionica. $\mathrm{Na}$ rodne novine 38/2010, 130/2010, 69/2011, $15 / 2012,151 / 2014$

Puharić, Z., Kudumija Sljepčević, M., Badrov, T. i Petričević, N. (2016). Gambling among Teenagers in Bjelovar-Bilogora County (Croatia). Alcoholism and Psychiatry Research, 52, 5-16.

Ricijaš, N. i Dodig Hundrić, D. (2019). Izvještaj o rezultatima istraživanja kockanja $i$ štetne uporabe interneta srednjoškolaca na području Zadarske županije. Izvještaj projekta "Mentalno zdravlje za sve" Zavoda za javno zdravstvo Zadarske županije.

Ricijaš, N., Dodig Hundrić, D. i Kranželić, V. (2015). Sportsko klađenje i druga rizična ponašanja hrvatskih srednjoškolaca. Hrvatska revija za rehabilitacijska istraživanja, 51(2) 4156.

Ricijaš, N., Dodig Hundrić, D., Huić, A. i Kranželić, V. (2016). Kockanje mladih u Hrvatskoj - učestalost igranja i zastupljenost problematičnog kockanja. Kriminologija i socijalna integracija, 24(2), 24-47. DOI: https://doi.org/10.31299/ ksi.24.2.2 
Ricijaš, N., Mladi s problemima kockanja - koliko kockaju i kako vide industriju igara na sreću, Klinička psihologija 13 (2020), 1-2, 47-62

Ricijaš, N., Maglica, T. i Dodig Hundrić, D. (u tisku). Regulativa igara na sreću u Hrvatskoj kao socijalni rizik. Ljetopis socijalnog rada.

Sharman, S., Butler, K. i Roberts, A. (2019). Psychosocial risk factors in disordered gambling: A descriptive systematic overview of vulnerable populatioins. Addictive Behaviors, 99. DOI: https://doi.org/10.1016/j.addbeh.2019.106071

St-Piere, R. A., Wlker, D. M., Derevensky, J. i Gupta, R. (2014). How Availability and Accessibility of Gambling Venues Influence Problem Gambling: A Review of the Literature. Gaming Law Review and Economics, 18(2), 150-172. DOI: https://doi.org/10.1089/glre.2014.1824.

Sulkunen, P., Babor, T. F., Ornberg, J. C., Egerer, M., Hellman, M., Livingstone, C., Marionneau, V., Nikkinen, J., Orford, J., Room, R. i Rossow, I. (2019). Setting Limits - Gambling, Science, and Public Policy. Oxford: Oxford University Press

Thrasher, R. G., Andrew, D. P. S. i Mahony, D. F. (2007). The Efficacy of the Theory of Reasoned Action to Explain Gambling Behavior in College Students. The College Student Affairs Journal, 27(1), 57-75. DOI: 10.1007/s10899$010-9215-\mathrm{z}$
Tremblay, J., Stinchfield, R., Wiebe, J. i Wynne, H. (2010). Canadian Adolescent Gambling Inventory (CAGI) Phase III Final Report. Submitted to the Canadian Centre on Substance Abuse and the Interprovincial Consortium on Gambling Research.

Vasiliadis, S. D., Jackson, A. C., Christensen, D. i Francis, K. (2013). Psysical accessibility of gaming opportunity and its relationship to gaming involvement and problem gambling: A systematic review. Journal of Gambling Issues, 28, 1-46. DOI: http://dx.doi.org/10.4309/ jgi.2013.28.2.

Venus, M., Brlas, S. i Šerepac, V. (2013). Istraživanje o pušenju, alkoholu, kockanju, drogama $i$ slobodnom vremenu medu učenicima $u$ Virovitičko-podravskoj županiji. Virovitica: Zavod za javno zdravstvo "Sveti Rok" Virovitičko-podravske županije.

Volberg, R. A., Gupta, R., Griffiths, M. D., Olason, D. T. i Delfabbro, P. (2010). An international perspective on youth gambling prevalence studies. International Journal of Adolescent Medicine and Health, 22(1), 3-38.

Zakon o igrama na sreću. Narodne Novine 87/09, 35/13, 158/13, 41/14, 143/14.
Korespondencija: Neven Ricijaš

Edukacijsko-rehabilitacijski fakultet Sveučilišta u Zagrebu, Borongajska 83 f, 10000 Zagreb

neven.ricijas@erf.unizg.hr
Primljeno: 08.03 .2020$.

Prihvaćeno: 24. 09. 2020

Online: $\quad 30.10 .2020$

Print: $\quad$ 27.11.2020.

\section{Youth Problem Gamblers - Their Frequency of Gambling and the Perception of the Gambling Industry}

Summary: Although legally prohibited, juvenile gambling and consequentially developed adverse psychosocial consequences, attract increased scientific and professional attention of mental health professionals, especially due to the vulnerability for the development of a gambling addiction. The aim of this paper is to explore differences in the frequency of youth gambling with regard to the level of developed adverse psychosocial consequences, and specifically their perception of availability and accessibility of gambling venues in Croatia. 
The study included a convenient sample of $\mathrm{N}=615$ male high school students from Zagreb and Split (Mage $=16.16$; SDage $=1.21$ ) of all three types of educational programs, from the first to the final grade. Beside the basic sociodemographic variables, the study used the Gambling Activity Questionnaire, Gambling Problem Severity Subscale (GPSS) and the Gambling Industry Perception Questionnaire. In addition to the descriptive statistics and correlations, ANOVA and Kruskal-Wallis tests were performed, with their respective post-hoc tests.

The results show that adolescents who, according to the GPSS score, have a high-level of adverse psychosocial consequences related to gambling (e.g. red light) gamble more frequently, especially high-risk games (sports betting and slot machines), they perceive games and gambling venues as more accessible to minors (despite legal prohibitions), and are of the opinion that the state should prescribe a lower age $(<18)$ for legal inclusion in gambling. The results unambiguously point to the more intensive risky behaviour of young people who have developed gambling related psychosocial problems, and their more liberal perception of the gambling industry in Croatia, as well as the increased accessibility to minors.

The results are interpreted in accordance with previous youth gambling studies in Croatia, as well as the indirect importance of the impact the gambling market has on the attitudes of young people and the normalization of this risky industry. This is especially true in the context of expanded accessibility and accessibility in our country.

Key words: gambling, adolescents, gambling industry, gambling addiction 